\title{
DISTRIBUTION OF FEDERAL TAXES AND \\ EXPENDITURES: URBAN VS. RURAL STATES
}

\author{
Elliott Dubin
}

\begin{abstract}
The spatial allocation of federal expenditures and tax burdens has changed dramatically during the 1980 s because of major changes in federal budget priorities and significant changes to the Internal Revenue Code. This study examines changes in the regional net flow of federal funds (the difference between federal expenditures within a region and federal tax burdens bome by the residents of that region) for the periods 1981-83 and 1987-89. The major findings of this study are that federal fiscal activities moderately redistribute resources from higher to lower income regions, and that, with some exceptions, changes in the net flow of federal funds by region have been due to changes in the geographic distribution of federal tax burdens.
\end{abstract}

\section{INTRODUCTION}

In 1990, federal expenditures were approximately 23 percent of Gross National Product (Bureau of Economic Analysis 1991, 7, 12). Therefore, federal expenditures are obviously an important factor shaping a region's economy. On a micro level, federal expenditures affect, to some extent, a region's economic development and income level. For example, defense expenditures are relatively concentrated geographically, and thus strongly affect those areas heavily dependent on federal purchases or defense wages and salaries. Similarly, federal farm assistance payments affect those places dependent on agriculture. Also, the geographic portability of Social Security benefits and federal pensions allows retirees to live in places of their choice, thus affecting the demographic and economic development of areas receiving these migrants.

Most of the literature on the geographic aspect of federal fiscal activities focuses on the expenditure side of the budget equation only. ${ }^{1}$ However, federal tax policies can also affect a region's economy. The geographic distribution of federal tax burdens results from both the existing tax rate and base structure and the geographic distribution of income (both level and type) and by consumption patterns and other factors. ${ }^{2}$ Thus, the geographic distribution of tax burdens would change over time according to changes in the geographic distribution of the level and types of income, consumption patterns, and changes in the tax structure. For example, the federal tax system underwent four major changes during the

\footnotetext{
Analyst, U.S. Advisory Commission on Intergovernmental Relations. Views reflected here are those of the author and may not reflect the view of the Advisory Commission on Intergovernmental Relations.
} 
1980-1990 decade, which according to the House Budget Committee (1990, 20, 61), made the overall federal tax system less progressive in 1990 than in 1980 because of increasing reliance on payroll taxes. ${ }^{3}$ This assumption implies that, if the geographic distribution of the bases on which these taxes are imposed had remained constant between 1980 and 1990, federal tax burdens would have risen more rapidly in those regions heavily dependent on wage and salary (payroll) income than in those areas that rely more on interest, dividend, rent, and royalty income, since the latter forms of income are not subject to payroll taxes.

The purpose of this study is to describe the changes in the net flow of federal funds among states and regions during the 1980s and to attempt to attribute those changes to changes in the geographic distribution of expenditures and tax burdens. The net flow of funds is measured by the difference between federal expenditures received within a geographic area and federal tax burdens borne by the residents of that area. Using a typology of states developed by the Economic Research Service of the U.S. Department of Agriculture (which will be discussed later), this study focuses on the changes in the net flow of federal funds in urban and rural states in general, and in farm-dependent, low-income, and retirementdestination states in particular. The study also presents data on the net flow of federal funds in Bureau of Economic Analysis regions. ${ }^{4}$

The findings of this study can be used to answer two related questions: 1) Do the fiscal activities of the federal government redistribute fiscal resources from higher income areas to lower income areas; and 2) Does the fiscal system respond to changes in economic circumstances? Because it serves a multitude of purposes and uses a wide variety of revenue sources to fund the programs, the federal fiscal system cannot be expected to redistribute resources from high income to low income areas to an appreciable extent.

Fiscal resources are redistributed from high income areas to lower income areas, because of the progressivity of the federal tax system, . Federal expenditures are often distributed in a progressive fashion (i.e., high income areas get high per capita expenditures). This type of distribution is true to some extent for defense spending and grants for research. Retirement and income transfers go to recipients regardless of the average level of income of the area in which they reside. Grants to state and local governments for highway construction and other major capital expenditures are funded on a project-by-project basis and are not designed to equalize fiscal resources across regions. In the aggregate, only a small portion of federal expenditures are designed to equalize fiscal resources by region.

Section II discusses the methodology used and the sources of data. Section III is a discussion of the major findings, and Section IV is the summary/conclusions. 


\section{METHODOLOGY}

\section{Expenditures}

This study examines the geographic distribution of federal expenditures for the fiscal 1981-83 period and fiscal 1987-89 period. Three-year averages are used to smooth out any unusually large annual fluctuations that may occur. Expenditures are classified as total expenditures, defense, and nondefense expenditures. Data on federal expenditures are provided by the U.S. Department of Commerce, Bureau of the Census (Census 1989), which is the only complete source of information on state-by-state distribution of federal expenditures. ${ }^{5}$ The most significant exclusion from the Census coverage of expenditures is interest on the federal debt. Other exclusions are 1) expenditures for selected agencies such as the Central Intelligence Agency and the National Security Agency; and 2) federal procurement contracts under $\$ 25,000$. $^{6}$

The exclusion of interest payments on the federal debt presents a significant obstacle to obtaining estimates of the geographic distribution of federal expenditures. Net interest payments represented 10.9 percent of federal outlays in 198183 and 14.3 percent of outlays in 1987-89 (Office of Management and Budget 1991). However, computational problems would have arisen had the Census Bureau reported interest payments at the point of initial incidence. Federal debt is held mainly for their own purposes by financial institutions such as banks, pension funds, and insurance companies and as fiduciaries for individuals. If it is possible to segregate total interest payments made to financial institutions into fiduciary and nonfiduciary amounts, a consensus would have to be reached regarding the allocation, by geographic area, of the interest payments on the holdings of federal debt in fiduciary accounts.

Federal intervention in credit markets also affects local economies by reallocating financial resources. Local economies that are able to borrow directly from the U.S. Treasury or obtain a federally guaranteed loan receive a subsidy because they are able to borrow on more favorable terms than can be provided by purely private market transactions. This interest subsidy can be viewed as equivalent to a grant. The U.S. Office of Management and Budget (Special Analysis, Section F, various fiscal years) calculates the interest rate subsidy resulting from federal credit activities by estimating the differences in payments (including loan origination and commitment fees) a borrower would make between a purely private market loan and a federal loan, and discounting the differences by a measure of private internal rate of return (OMB 1988, F-42).

Estimates of the interest subsidies resulting from federal credit activities were added to the data on expenditures provided by the Census Bureau to arrive at 
estimates of total expenditures. State-by-state estimates of the interest subsidies were derived by multiplying the OMB estimated subsidy for particular types of loans (e.g., guaranteed student loans, rural development, etc.) by the state distribution of those loans which were provided by the Census Bureau (Federal Expenditures by State, Table 7, various fiscal years). Loans for foreign military sales, and loans made and guaranteed by the Agency for International Development and the Overseas Private Investment Corporation were excluded from this analysis.

The interest rate subsidies included in this study were $\$ 17,570$ million in 1981-83 and $\$ 12,205$ million in 1987-89. This sharp decline in the value of interest subsidies occurred despite the fact that new federal lending, both direct and guaranteed, rose from $\$ 131.4$ billion in 1981-83 to $\$ 146.4$ billion in 1987-89 (OMB various fiscal years). Part of the decline can be explained by the shift from direct loans to guaranteed loans. Interest subsidies constitute approximately 32 percent of direct federal loans, but only 4.5 percent of guaranteed loans (OMB 1991, 245-246). In 1981-83, direct loans were 42 percent of the total of new direct and guaranteed loans, but only 21.6 percent in 1987-89 (OMB 1983, 1989, and 1991, 233).

It should be noted here that federal expenditures are not necessarily a good measure of the benefits received by the residents of the states where the expenditures are made. For example, the benefits of expenditures for national defense are received by all residents, regardless of the location of the expenditures. ${ }^{7}$ Other types of expenditures, as noted by Bahl and Warford (1971) and Tolley, Krum, and Garcia (1986, 7-23), such as highway construction and water supply projects, also have significant "spillover" effects (i.e., the benefits of these expenditures are received by residents outside of the state where the spending takes place). ${ }^{8}$ In addition, the benefits of some expenditures, such as those for education and research, accrue over long periods of time, so that current expenditures do not measure current benefits.

The expenditure data also suffer from biases due to the method of reporting used by the Census Bureau. Procurement contracts are reported at the place of performance, and wages and salaries are reported at the location of the place of employment. In the case of procurement contracts, bias results from subcontracting in which the work is not performed at the place reported by the Census Bureau. How much bias results from unreported subcontracting is not clear. Anton $(1983,434)$ believes that prime contracts are a good indicator of military spending, while McKenzie $(1982,32)$ argues that these data are unreliable, since at least 50 percent of all contracts are subject to subcontracting.

A similar, but smaller, bias exaggerates reported federal wages and salaries. If the data were reported at the place of residence rather than at the place of employment, certain states (e.g., New York, Pennsylvania, and the District of 
Columbia) would have lower reported wages and salaries, while Connecticut, New Jersey, Maryland, and Virginia would have higher reported wages and salaries because of substantial interstate commuting.

\section{Tax Burdens}

Estimates of federal tax burdens attempt to measure the ultimate geographic incidence of taxes rather than the initial incidence (where the tax is collected); thus, estimates of tax burdens by state may differ from collections. For example, federal excise taxes on distilled spirits and tobacco products are generally collected in a few Southeastern states. Economic theory states that taxes on these products are for the most part passed forward to the ultimate consumers. Therefore, the burden of these taxes is assumed to be borne by the adult population of the geographic areas in the analysis and not at the location of the production of these products. ${ }^{9}$

The question of the ultimate incidence of other taxes such as corporate income taxes, payroll taxes, and certain excise taxes is not yet settled. Because business firms do not bear the burden of taxes, but act as a conduit between the government and individuals in their capacities as consumers and producers, answers to these questions involve determination of the proportion of the tax that is passed forward to the ultimate consumer and the proportion that is passed backward to the factors of production. These proportions will vary with the degree of market power of firms and the elasticity of demand and supply for the products and services being taxed. Assumptions of the ultimate incidence of these taxes, which differ from Tax Foundation's, will therefore yield different estimates of the geographic distribution of federal tax burdens. ${ }^{10}$

Data on federal tax burdens by state and the bases used to allocate the various federal taxes are provided by Merski $(1990,2,6)$ and the Tax Foundation (1988). The estimates of total tax burdens by states are averaged over fiscal years 1981-1983 and 1987-1989 to make them comparable to the expenditure data. Estimates of federal tax burdens to finance defense expenditures are obtained by averaging the federal funds tax burden over these same time periods. ${ }^{11}$ The bases used by the Tax Foundation to allocate the various federal taxes are presented in Table 1. For a detailed explanation of the methods used to allocate the burden of taxes and the underlying rationale, see Tax Foundation, Inc. (1974).

Estimates of the tax burden borne by residents of each state to support federal spending are derived by multiplying the proportion of the federal tax burden borne by the residents of each state by total U.S. spending. For example, total federal expenditures in the 1987-89 period were $\$ 870.1$ billion, and the share of the federal tax burden borne by the residents of the New England states was 6.5 
TABLE 1

Bases for Allocating the Federal Tax Burden by State (Fiscal Year 1989)

\begin{tabular}{cc}
\hline \hline Tax & Base \\
\hline
\end{tabular}

\section{Federal Fund Taxes}

Individual income

Corporate income

Alcoholic beverages

Tobacco

Estate and gift

Other excises and customs

\section{Trust Fund Taxes}

Old Age Survivors, Disability, and Hospitalization (OASDHI); Railroad Retirement; Federal Unemployment Insurance

State unemployment insurance taxes deposited with the U.S. Treasury

Highway Trust Fund

Gasoline, diesel fuel, special fuels, lubricating oil, and heavy vehicle use

Trucks and buses, parts and accessories, tires, tubes, and tread rubber

Airport and Airway Trust Fund, Black Lung Disability Trust Fund, and other trust funds
Individual income tax liability (1987) adjusted by 1988 changes in personal income (Internal Revenue Service)

$1 / 2$ personal income ${ }^{1}(1988)$

$1 / 2$ property income ${ }^{2}(1988)$

(Department of Commerce)

$1 / 2$ total adult population; July 1,1988

$1 / 2$ consumption data (1988)

(U.S. Brewers Association)

Total adult population; July 1, 1

Six-year total of estate and gift tax collections: 1984-89

(Internal Revenue Service)

Disposable personal income (1988)

(Department of Commerce)

$1 / 2$ personal income ${ }^{1}$ (1988)

$1 / 2$ personal contributions for social insurance $^{3}$ (1988)

(Department of Commerce)

Unemployment tax collections (1988)

(Department of Labor)

Motor fuel excise data (1988)

(Department of Transportation)

Truck and bus excise data (1988)

(Department of Transportation)

Disposable personal income (1988)

(Department of Commerce)

${ }^{1}$ Personal income by place or residence.

${ }^{2}$ Largely intangible interest and dividend income.

${ }^{3}$ Adjusted for place of residence.

Source: Paul G. Merski, "Federal Tax Burden by State," Special Report, Tax Foundation, Inc. Washington, D.C.: U.S. Government Printing Office, May 1990. 
percent; the tax burden on New Englanders was $\$ 58.2$ billion (6.5 percent of $\$ 870.1$ billion).

\section{State Typologies}

The state typologies used in this study and their definitions are presented in Table 2. These typologies were developed by the Economic Research Service of the Department of Agriculture and parallel their county typologies (Dubin 1989). States are classified as urban, rural, and other, according to the proportion of the 1980 population residing in urban areas within metropolitan areas (these categories are mutually exclusive). The other classifications-farm dependent, low income, and retirement destination-are not mutually exclusive. For example, Arkansas is classified as farm dependent, low income, and retirement destination.

The next section presents the major findings concerning the distributions of federal expenditures and federal tax burdens and the net flow of federal funds across types of states and Bureau of Economic Analysis (BEA) regions.

\section{GEOGRAPHIC REDISTRIBUTION OF FISCAL RESOURCES}

Geographic redistribution of fiscal resources, during any time period, occurs because federal expenditures in a particular area do not always match the federal tax burdens borne by the residents of that area. Over time, changes in budget priorities and the composition of spending by type change the geographic distribution of spending. Similarly, federal tax structures and regional economic conditions change, altering the distribution of federal tax burdens. Each of these changes results in changes in the geographic distribution of fiscal resources.

The data presented in Table 3 illustrate how federal fiscal activities redistribute fiscal resources among regions and types of states. For example, in the $1981-83$ period, rural states received $\$ 84.8$ billion in federal expenditures, while the residents of those states bore a federal tax burden of $\$ 76.3$ billion (12.07 percent of $\$ 632.5$ billion). Therefore, rural states received a net inflow of $\$ 8.5$ billion ( $\$ 249$ per capita). Conversely, residents of urban states had federal tax burdens totalling $\$ 329.4$ billion and received $\$ 324.0$ billion in federal expenditures, a net outflow of federal funds of $\$ 5.4$ billion ( $\$ 49$ per capita). The East North Central (Great Lakes) region experienced net outflows of federal funds of nearly $\$ 700$ per capita in both the $1981-83$ and $1987-89$ periods. As noted by Erdevig (1986), this region enjoys above-average income levels resulting in aboveaverage tax burdens, lacks large defense installations, and does not produce goods and services purchased directly by the federal government. 
TABLE 2

Classification of States

\begin{tabular}{|c|c|c|c|c|c|c|c|}
\hline \multirow[b]{2}{*}{ State } & \multirow[b]{2}{*}{$\begin{array}{c}\text { Popu- } \\
\text { lation } \\
1987-89 \\
\text { (Thousands) }\end{array}$} & \multicolumn{6}{|c|}{ Type of State ${ }^{1}$} \\
\hline & & $\begin{array}{c}\text { Urban/ } \\
\text { metro }\end{array}$ & $\begin{array}{c}\text { Rural/ } \\
\text { Small } \\
\text { town }\end{array}$ & Other & $\begin{array}{c}\text { Farm } \\
\text { depend- } \\
\text { ent }\end{array}$ & $\begin{array}{c}\text { Low } \\
\text { income }\end{array}$ & $\begin{array}{c}\text { Retire- } \\
\text { ment } \\
\text { des- } \\
\text { tination }\end{array}$ \\
\hline Alabama & 4,101 & & & $\mathbf{X}$ & & $\mathbf{X}$ & \\
\hline Alaska & 525 & & & $\mathbf{X}$ & & & \\
\hline Arizona & 3,477 & $X$ & & & & & $\mathrm{X}$ \\
\hline Arkansas & 2,396 & & $\mathrm{X}$ & & $\mathbf{X}$ & $\mathbf{X}$ & $\mathrm{X}$ \\
\hline California & 28,347 & $\mathrm{X}$ & & & & & \\
\hline Colorado & 3,305 & $\mathbf{X}$ & & & & & \\
\hline Connecticut & 3,228 & $\mathrm{X}$ & & & & & \\
\hline Delaware & 659 & & & $\mathbf{X}$ & & & \\
\hline District of Columbia & 614 & $\mathbf{X}$ & & & & & \\
\hline Florida & 12,343 & $\mathrm{X}$ & & & & & $X$ \\
\hline Georgia & 6,333 & & & $\mathrm{X}$ & & & \\
\hline Hawaii & 1,098 & $\mathrm{X}$ & & & & & $\mathrm{X}$ \\
\hline Idaho & 1,005 & & $\mathrm{X}$ & & $\mathrm{X}$ & & \\
\hline Illinois & 11,618 & $\mathrm{X}$ & & & & & \\
\hline Indiana & 5,560 & & & $\mathrm{X}$ & & & \\
\hline Iowa & 2,836 & & $\mathbf{X}$ & & $\mathrm{X}$ & & \\
\hline Kansas & 2,495 & & $\mathrm{X}$ & & $\mathrm{X}$ & & \\
\hline Kentucky & 3,727 & & $\mathrm{X}$ & & & $\mathrm{X}$ & \\
\hline Louisiana & 4,417 & & & $\mathbf{X}$ & & & \\
\hline Maine & 1,205 & & $\mathbf{X}$ & & & & \\
\hline Maryland & 4,617 & $\mathrm{X}$ & & & & & \\
\hline Massachusetts & 5,886 & $\mathrm{X}$ & & & & & \\
\hline Michigan & 9,238 & & & $X$ & & & \\
\hline Minnesota & 4,302 & & & $\mathbf{X}$ & $\mathrm{X}$ & & \\
\hline Mississippi & 2,622 & & $X$ & & $X$ & $\mathrm{X}$ & \\
\hline Missouri & 5,134 & & & $\mathbf{X}$ & & & \\
\hline Montana & 807 & & $\mathbf{X}$ & & $\mathbf{X}$ & & \\
\hline Nebraska & 1,602 & & $\mathbf{X}$ & & $\mathrm{X}$ & & \\
\hline Nevada & 1,057 & $\mathbf{X}$ & & & & & $\mathbf{X}$ \\
\hline New Hampshire & 1,083 & & $\mathbf{X}$ & & & & \\
\hline New Jersey & 7,710 & $\mathrm{X}$ & & & & & \\
\hline New Mexico & 1,512 & & $\mathbf{X}$ & & & & $\mathrm{X}$ \\
\hline New York & 17,895 & $\mathrm{X}$ & & & & & \\
\hline North Carolina & 6,491 & & $\mathrm{X}$ & & & & \\
\hline North Dakota & 666 & & $\mathbf{X}$ & & $\mathbf{X}$ & & \\
\hline Ohio & 10,849 & & & $\mathbf{X}$ & & & \\
\hline Oklahoma & 3,246 & & & $\mathrm{X}$ & & & \\
\hline Oregon & 2,770 & & & $\mathbf{X}$ & & & \\
\hline Pennsylvania & 11,992 & & & $\mathbf{X}$ & & & \\
\hline Rhode Island & 992 & $X$ & & & & & \\
\hline South Carolina & 3,469 & & $X$ & & & $X$ & \\
\hline South Dakota & 712 & & $X$ & & $X$ & & \\
\hline Tennessee & 4,897 & & & $X$ & & $\mathrm{X}$ & \\
\hline Texas & 16,874 & $\mathrm{X}$ & & & & & \\
\hline Utah & 1,692 & $X$ & & & & & \\
\hline Vermont & 557 & & $X$ & & & & \\
\hline Virginia & 6,006 & & & $\mathrm{X}$ & & & \\
\hline Washington & 4,649 & & & $\mathrm{X}$ & & & \\
\hline West Virginia & 1,877 & & $\mathrm{X}$ & & & $\mathrm{X}$ & \\
\hline Wisconsin & 4,843 & & & $\mathbf{X}$ & & & \\
\hline Wyoming & 481 & & $\mathrm{X}$ & & & & \\
\hline All States & 245,816 & 120,752 & 35,543 & 89,521 & 19,444 & 23,089 & 21,883 \\
\hline
\end{tabular}

Notes on the following page. 
TABLE 2 (Continued)

${ }^{1}$ Rural: 41 percent or less of the state's population (1980) residing in rural places within metropolitan areas as defined in 1980.

Urban: 70 percent or more of the state's population (1980) residing in urban places within metropolitan areas as defined in 1980.

Other: More than 41 percent, and less than 70 percent of the state's population residing in urban areas within metropolitan areas as defined in 1980.

Farm dependent: States with labor eamings from farming greater than 6 percent of total labor eamings, $1975-79$. Low Income: states with per capita personal income in bottom quintile of states in 1959, 1969, 1979, and 1985. Retirement destination: States with 15 percent or more aged (over 59) population in 1980 due to net inmigration from 1970 to 1980 .

Source: U.S. Advisory Commission on Intergovernmental Relations, Significant Features of Fiscal Federalism, 1989, Volume II, p. 4. U.S. Department of Commerce, Bureau of the Census, Federal Expenditures by State for Fiscal Year 1989, p. 27.

\section{TABLE 3}

Federal Expenditures and Federal Tax Burdens

Average of Fiscal Years 1981-83 and 1987-89

By Type of State and Geographic Region

(Millions of Dollars except Per Capita)

\begin{tabular}{|c|c|c|c|c|c|c|c|c|}
\hline \multirow[b]{3}{*}{$\begin{array}{l}\text { Type of state } \\
\text { and region }\end{array}$} & \multicolumn{4}{|c|}{$1981-83$} & \multicolumn{4}{|c|}{$1987-89$} \\
\hline & \multirow{2}{*}{$\begin{array}{c}\text { Federal } \\
\text { expendi- } \\
\text { tures }\end{array}$} & \multirow{2}{*}{$\begin{array}{c}\text { Federal } \\
\text { tax } \\
\text { burden } \\
\end{array}$} & \multicolumn{2}{|c|}{ Expenditures-Taxes } & \multirow{2}{*}{$\begin{array}{c}\text { Federal } \\
\text { expendi- } \\
\text { tures }\end{array}$} & \multirow{2}{*}{$\begin{array}{c}\text { Federal } \\
\text { tax } \\
\text { burden } 1\end{array}$} & \multicolumn{2}{|c|}{ Expenditures-Taxes } \\
\hline & & & Total & $\begin{array}{c}\text { Per } \\
\text { capita }\end{array}$ & & & Total & $\begin{array}{c}\text { Per } \\
\text { capita }\end{array}$ \\
\hline All States & $\$ 632,516$ & $\$ 632,516$ & $\$ 0$ & \$o & $\$ 870,105$ & $\$ 870,105$ & \$o & \$0 \\
\hline Rural & 84,820 & 76,326 & 8,494 & 249 & 120,115 & 98,381 & 21,734 & 611 \\
\hline Urban & 324,004 & 329,416 & $(5,412)$ & (49) & 445,913 & 477,258 & $(31,345)$ & $(260)$ \\
\hline Other & 223,693 & 226,774 & $(3,082)$ & (36) & 304,077 & 294,466 & 9,611 & 107 \\
\hline Farm & 47,932 & 45,986 & 1,945 & 102 & 69,798 & 56,573 & 13,224 & 680 \\
\hline Low income & 55,838 & 45,393 & 10,446 & 469 & 76,310 & 58,915 & 17,394 & 753 \\
\hline Retirement & 55,325 & 46,293 & 9,032 & 485 & 81,691 & 72,201 & 9,489 & 434 \\
\hline New England & 39,761 & 37,011 & 2,750 & 221 & 53,839 & 58,190 & $(4,351)$ & (336) \\
\hline Mid Atlantic & 126,074 & 126,946 & $(872)$ & (21) & 168,717 & 183,774 & $(15,057)$ & $(346)$ \\
\hline E. North Cen. & 90,253 & 119,106 & $(28,853)$ & (693) & 120,424 & 148,992 & $(28,568)$ & $(678)$ \\
\hline W. North Cen. & 48,008 & 45,792 & 2,216 & 128 & 68,061 & 57,531 & 10,530 & 593 \\
\hline Southeast & 145,397 & 122,926 & 22,471 & 416 & 204,491 & 175,254 & 29,237 & 498 \\
\hline Southwest & 56,944 & 61,305 & $(4,362)$ & (195) & 83,355 & 78,581 & 4,774 & 190 \\
\hline Rocky Mt. & 18,397 & 17,523 & 874 & 128 & 27,632 & 21,551 & 6,081 & 834 \\
\hline Pacific & 107,681 & 101,907 & 5,774 & 171 & 143,584 & 146,231 & $(2,647)$ & (69) \\
\hline East & 165,835 & 163,957 & 1,879 & 34 & 222,555 & 241,964 & $(19,409)$ & (344) \\
\hline Midwest & 138,261 & 164,897 & $(26,636)$ & $(452)$ & 188,486 & 206,523 & $(18,037)$ & $(301)$ \\
\hline South & 189,045 & 174,413 & 14,632 & 203 & 266,751 & 239,240 & 27,511 & 349 \\
\hline West & 139,374 & 129,249 & 10,126 & 227 & 192,313 & 182,378 & 9,935 & 196 \\
\hline
\end{tabular}

${ }^{1}$ The total federal tax burden is assumed to be equal to federal expenditures. Based on the distribution of the total federal tax burden.

Source: Bureau of the Census, Federal Expenditures by State for Fiscal Year 1989, Table 11. Tax Foundation, Inc. "Memorandum on the Allocation of the Federal Tax Burden and Grants-in-Aid by State, Fiscal Year 1988;" and Paul Merski, "Federal Tax Burden by State," Special Report. Tax Foundation, Inc., May 1990. 
Although it is not readily apparent from the regional data, the net effect of federal spending and taxing is to modestly redistribute resources from higher income areas to lower income areas. Using ordinary least squares (OLS) regressions, I regressed per capita net flow of federal funds (expenditures-taxes), by state, on state per capita personal income. It was found that in 1987-89, for example, a $\$ 1.00$ change in state per capita personal income was associated with a change of $\$ .57$, in the opposite direction, in the per capita net flow of federal funds. When Alaska, Hawaii, and the District of Columbia (DC) were excluded, the per capita net flow of federal funds changed by $\$ .87$ for each $\$ 1.00$ change in state per capita personal income. (See Table 4 for details.)

With the exception of the Great Lakes region, where per capita net outflows of federal funds were $\$ 693$ in 1981-83 and $\$ 678$ in 1987-89, every region experienced major shifts in the net flow of federal funds between 1981-83 and $1987-89$. For example, per capita net inflows to rural states increased by $\$ 362$ from $\$ 249$ in 1981-83 to $\$ 611$ in 1987-89. Similarly, per capita inflows to farm states were $\$ 578$ higher in 1987-89 than in 1981-83. Conversely, urban states experienced a significant increase in net outflows of funds between 1981-83 and $1987-89-$ from $\$ 5.4$ billion ( $\$ 49$ per capita) to $\$ 31.3$ billion ( $\$ 260$ per capita). The Rocky Mountain region experienced a $\$ 706$ per capita rise in the net inflow of federal funds, the largest change among all the BEA regions. In New England, the net flow of federal funds turned around from a $\$ 221$ per capita net inflow in $1981-83$ to a per capita net outflow of $\$ 336$ in 1987-89. The reverse occurred in the Southwest-a $\$ 195$ per capita net outflow became a $\$ 190$ per capita net inflow (Table 3). ${ }^{12}$

Regional net flows of funds change over time because federal expenditures and tax burdens change at different rates (Table 5). An extreme example of the differing growth rates of federal expenditures and tax rates occurred in the Rocky Mountain region. Between 1981-83 and 1987-89, per capita expenditures in that region grew by 5.8 percent annually, compared to 4.3 percent annually for the nation as a whole. Per capita federal tax burdens to support expenditures in that region, however, grew by only 2.4 percent annually. The differences in the growth rates in expenditures and corresponding tax burdens resulted in a change from a $\$ 128$ per capita net inflow in $1981-83$ to an $\$ 834$ per capita net inflow in 198789-a $\$ 706$ per capita change (Table 3). Conversely, in New England the change from a net inflow of $\$ 221$ per capita in 1981-83 to a net outflow of $\$ 336$ per capita in 1987-89 was the result of per capita expenditures rising at an average annual rate of 4.5 percent, while per capita tax burdens were rising at an average annual rate of 7.1 percent (Table 5).

While all types of states and BEA regions experienced increases in per capita federal expenditures, the increases were not uniformly distributed across the types 
TABLE 4

State Per Capita Net Flow Relative to Per Capita Income

\begin{tabular}{|c|c|c|c|c|}
\hline \multirow[b]{2}{*}{ Statistic } & \multicolumn{2}{|c|}{ All states ${ }^{1}$} & \multicolumn{2}{|c|}{$\begin{array}{l}\text { Excluding Alaska, } \\
\text { Hawaii, and DC }\end{array}$} \\
\hline & Constant & $\begin{array}{l}\text { Per Capita } \\
\text { Income }\end{array}$ & Constant & $\begin{array}{c}\text { Per Capita } \\
\text { Income }\end{array}$ \\
\hline & \multicolumn{4}{|c|}{ 1981-83 } \\
\hline & \multicolumn{4}{|c|}{ Total expenditures } \\
\hline \multirow[t]{2}{*}{$\begin{array}{l}\text { Coefficient } \\
\text { (t) statistic } \\
\text { R Squared }\end{array}$} & $\begin{array}{r}-2366.5 \\
-1.0809 \\
0.0367\end{array}$ & $\begin{array}{c}0.2689 \\
1.3656\end{array}$ & $\begin{array}{c}2,121.7 \\
4.2593^{*} \\
0.2264\end{array}$ & $\begin{array}{l}-0.1970 \\
-3.6691\end{array}$ * \\
\hline & \multicolumn{4}{|c|}{ Defense expenditures } \\
\hline \multirow[t]{2}{*}{$\begin{array}{l}\text { Coefficient } \\
\text { (t) statistic } \\
\text { R Squared }\end{array}$} & $\begin{array}{r}-887.7 \\
-1.9520 \\
0.0887\end{array}$ & $\begin{array}{l}0.0893 \\
.3720^{*}\end{array}$ & $\begin{array}{r}-143.2 \\
-0.3826 \\
0.0016\end{array}$ & $\begin{array}{l}0.0110 \\
0.2715\end{array}$ \\
\hline & \multicolumn{4}{|c|}{ Nondefense expenditures } \\
\hline \multirow[t]{3}{*}{$\begin{array}{l}\text { Coefficient } \\
\text { (t) statistic } \\
\text { R Squared }\end{array}$} & $\begin{array}{r}-1478.8 \\
-0.7485 \\
0.0204\end{array}$ & $\begin{array}{l}0.1796 \\
1.0107\end{array}$ & $\begin{array}{c}2,264.9 \\
7.5033 \\
0.4703\end{array}$ & $\begin{array}{l}-0.2080 \\
-6.3913^{*}\end{array}$ \\
\hline & \multicolumn{4}{|c|}{$1987-89$} \\
\hline & \multicolumn{4}{|c|}{ Total expenditures } \\
\hline \multirow[t]{2}{*}{$\begin{array}{l}\text { Coefficient } \\
\text { (t) Statistic } \\
\text { R Squared }\end{array}$} & $\begin{array}{r}8,492.5 \\
1.8167 \\
0.0950\end{array}$ & $\begin{array}{l}-0.5739 \\
-2.2676^{*}\end{array}$ & $\begin{array}{c}12,411.3 \\
2.9654 \\
0.2197\end{array}$ & $\begin{array}{l}-0.8701 \\
-3.5984\end{array}$ \\
\hline & \multicolumn{4}{|c|}{ Defense expenditures } \\
\hline \multirow[t]{2}{*}{$\begin{array}{l}\text { Coefficient } \\
\text { (t) statistic } \\
\text { R Squared }\end{array}$} & $\begin{array}{r}-742.3 \\
-1.3198 \\
0.0651\end{array}$ & $\begin{array}{l}0.0562 \\
1.8464\end{array}$ & $\begin{array}{r}-135.9 \\
-0.3122 \\
0.0027\end{array}$ & $\begin{array}{l}0.0089 \\
0.3533\end{array}$ \\
\hline & \multicolumn{4}{|c|}{ Nondefense expenditures } \\
\hline $\begin{array}{l}\text { Coefficient } \\
\text { (t) statistic } \\
\text { R Squared }\end{array}$ & $\begin{array}{r}91.1 \\
0.0358 \\
0.0013\end{array}$ & $\begin{array}{l}0.0344 \\
0.2495\end{array}$ & $\begin{array}{l}3,689.2 \\
7.5211 \\
0.5955\end{array}$ & $\begin{array}{l}-0.2332 \\
-8.2290^{\circ}\end{array}$ \\
\hline
\end{tabular}

${ }^{1}$ Number of observations $(N)=51$; degrees of freedom $(d f)=49$.

${ }^{2}$ Number of observations $(N)=48$; degrees of freedom $(d f)=46$.

"Significant at 95 percent level of confidence (Two-tailed test). 
TABLE 5

Per Capita Federal Expenditures and Tax Burdens

Average of Fiscal Years 1981-83 and 1987-89

and Average Annual Change 1981-83 to $1987-89$

\begin{tabular}{|c|c|c|c|c|c|c|}
\hline \multirow{3}{*}{$\begin{array}{l}\text { Type } \\
\text { of State } \\
\text { and Region }\end{array}$} & \multicolumn{3}{|c|}{ Federal expenditures } & \multicolumn{3}{|c|}{ Federal tax burdens } \\
\hline & \multicolumn{2}{|c|}{ Amount } & \multirow{2}{*}{$\begin{array}{c}\text { Average } \\
\text { annual } \\
\text { change } \\
1981-83 \\
\text { to } \\
1987-89\end{array}$} & \multicolumn{2}{|c|}{ Amount } & \multirow{2}{*}{$\begin{array}{c}\text { Average } \\
\text { annual } \\
\text { change } \\
1981-83 \\
\text { to } \\
1987-89\end{array}$} \\
\hline & $1981-83$ & $1987-89$ & & $1981-83$ & $1987-89$ & \\
\hline All States & $\$ 2,743$ & $\$ 3,540$ & $4.3 \%$ & $\$ 2,743$ & $\$ 3,540$ & $4.3 \%$ \\
\hline Rural & 2,483 & 3,379 & 5.3 & 2,235 & 2,768 & 3.6 \\
\hline Urban & 2,938 & 3,693 & 3.9 & 2,987 & 3,952 & 4.8 \\
\hline Other & 2,596 & 3,397 & 4.6 & 2,632 & 3,289 & 3.8 \\
\hline Farm & 2,523 & 3,590 & 6.1 & 2,420 & 2,910 & 3.1 \\
\hline Low income & 2,506 & 3,305 & 4.7 & 2,038 & 2,552 & 3.8 \\
\hline Retirement & 2,969 & 3,733 & 3.9 & 2,484 & 3,299 & 4.8 \\
\hline New England & 3,200 & 4,157 & 4.5 & 2,979 & 4,493 & 7.1 \\
\hline Mid Atlantic & 2,975 & 3,880 & 4.5 & 2,996 & 4,226 & 5.9 \\
\hline E. North Cen. & 2,168 & 2,860 & 4.7 & 2,861 & 3,538 & 3.6 \\
\hline W. North Cen. & 2,773 & 3,835 & 5.6 & 2,645 & 3,242 & 3.4 \\
\hline Southeast & 2,695 & 3,485 & 4.4 & 2,278 & 2,987 & 4.6 \\
\hline Southwest & 2,541 & 3,320 & 4.6 & 2,736 & 3,130 & 2.3 \\
\hline Rocky Mt. & 2,696 & 3,790 & 5.8 & 2,568 & 2,956 & 2.4 \\
\hline Pacific & 3,197 & 3,735 & 2.6 & 3,025 & 3,804 & 3.9 \\
\hline East & 3,026 & 3,943 & 4.5 & 2,992 & 4,287 & 6.2 \\
\hline Midwest & 2,346 & 3,149 & 5.0 & 2,798 & 3,450 & 3.6 \\
\hline South & 2,619 & 3,385 & 4.4 & 2,417 & 3,036 & 3.9 \\
\hline West & 3,118 & 3,791 & 3.3 & 2,891 & 3,595 & 3.7 \\
\hline
\end{tabular}

Source: Table 1.

of states and regions (Table 5). For example, per capita expenditures grew fastest in rural states in general and farm states in particular (5.3 percent and 6.1 percent annually, respectively) due to large inflows of farm assistance payments precipitated by the farm crisis. The BEA regions most heavily dependent on agriculture-the West North Central and Rocky Mountain regions-also ex- 
perienced the most rapid growth in per capita spending (5.6 percent and 5.8 percent annually).

Although per capita expenditure growth varies among regions, the per capita expenditure rankings remained fairly stable. The major exceptions were the Rocky Mountain region, which went from sixth to third, and the Pacific region, which went from second to fifth. This relative stability in rank of per capita expenditures is similar to what Anton $(1983,431)$ found in the previous decade. According to Lowery, Brunn, and Webster $(1988,49)$, the major shift in the spatial allocation occurred in the first year of the Reagan Administration (1981 to 1982) when the Northeast gained disproportionately due to the large increases in defense spending. After the initial change in the geographic distribution of spending, long-run changes in demographics, industrial mix, and migration alter the geographic distribution of spending because they determine the allocation needs and the size of the service population. In addition, changes in congressional makeup and electoral alignments, over time, can alter the spatial allocation of federal spending.

In contrast to the geographic distribution of federal expenditures, which is subject to numerous influences, the geographic distribution of federal tax burdens can be explained by variations in state personal income. In both 1981-83 and 1987-89, the simple correlation coefficients ( $r$ ) between state per capita federal tax burdens and state per capita personal income were .99 ; i.e., variations in state per capita Personal Income "explained" 97 percent of the interstate variance in per capita federal tax burdens $\left(r^{2}=.97\right)$. The correlation coefficient $(r)$ between the percentage change in state per capita federal tax burdens between 1981-83 and 1987-89 and the percentage change in state per capita personal income was .96 .

\section{Effects of Changes in the Distributions of Federal Expenditures and Tax Burdens}

The preceding analysis described the changes in the net flow of funds across regions and types of states. An interesting question arises: To what extent are the changes in the regional net flow of federal funds between 1981-83 and 1987-89 attributable to changes in the distributions of federal tax burdens and federal expenditures?

Table 6 presents estimates of the effect of changes in the distributions of federal expenditures and federal tax burdens on changes in the net flow of funds by region. The column labelled "Expenditures" represents the difference between actual 1987-89 expenditures and estimated expenditures based on the 1981-83 distribution of expenditures. Similarly, the column labelled "Tax burdens" represents the difference between actual tax burdens and tax burdens based on the 
TABLE 6

Difference in Net Flow of Federal Funds

By Type of State and Region, 1987-89

Due to Changes in the Distributions of Federal

Expenditures and Federal Tax Burdens ${ }^{1}$

\begin{tabular}{|c|c|c|c|c|c|c|}
\hline \multirow[b]{3}{*}{$\begin{array}{l}\text { Type of State } \\
\text { and Region }\end{array}$} & \multicolumn{6}{|c|}{ Difference in net flow of federal funds } \\
\hline & \multicolumn{3}{|c|}{ Total (millions) } & \multicolumn{3}{|c|}{ Per capita } \\
\hline & $\begin{array}{c}\text { Expendi- } \\
\text { tures }\end{array}$ & $\begin{array}{c}\text { Tax } \\
\text { burdens }\end{array}$ & $\begin{array}{c}\text { Dif- } \\
\text { ference }\end{array}$ & $\begin{array}{c}\text { Expendi- } \\
\text { tures }\end{array}$ & $\begin{array}{c}\text { Tax } \\
\text { burdens }\end{array}$ & $\begin{array}{c}\text { Dif- } \\
\text { ference }\end{array}$ \\
\hline & (1) & (2) & $\begin{array}{l}(3) \\
(1)-(2)\end{array}$ & (4) & (5) & $\begin{array}{c}(6) \\
(4)-(5)\end{array}$ \\
\hline All States & $\$ 0$ & $\$ 0$ & $\$ 0$ & $\$ 0$ & $\$ 0$ & \$o \\
\hline Rural & 3,435 & $(6,614)$ & 10,049 & 97 & (186) & 283 \\
\hline Urban & 205 & 24,105 & $(23,900)$ & 2 & 200 & (198) \\
\hline Other & $(3,640)$ & $(17,491)$ & 13,851 & (41) & (195) & 155 \\
\hline Farm & 3,861 & $(6,687)$ & 10,548 & 199 & (344) & 542 \\
\hline Low-income & $(503)$ & $(3,528)$ & 3,025 & (22) & (153) & 131 \\
\hline Retirement & 5,585 & 8,520 & $(2,935)$ & 255 & 389 & (134) \\
\hline New England & $(858)$ & 7,277 & $(8,134)$ & (66) & 562 & (628) \\
\hline Mid-Atlantic & $(4,714)$ & 9,145 & $(13,858)$ & (108) & 210 & (319) \\
\hline East-North-Central & $(3,730)$ & $(14,853)$ & 11,123 & (89) & $(353)$ & 264 \\
\hline West-North-Central & 2,020 & $(5,461)$ & 7,481 & 114 & (308) & 422 \\
\hline Southeast & 4,479 & 6,154 & $(1,675)$ & 76 & 105 & (29) \\
\hline Southwest & 5,022 & $(5,752)$ & 10,774 & 200 & (229) & 429 \\
\hline Rocky Mt. & 2,325 & $(2,555)$ & 4,879 & 319 & $(350)$ & 669 \\
\hline Pacific & $(4,545)$ & 6,046 & $(10,590)$ & (118) & 157 & (275) \\
\hline East & $(5,572)$ & 16,421 & $(21,993)$ & (99) & 291 & (390) \\
\hline Midwest & $(1,710)$ & $(20,314)$ & 18,604 & (29) & (339) & 311 \\
\hline South & 6,696 & (687) & 7,383 & 85 & (9) & 94 \\
\hline West & 586 & 4,580 & $(3,994)$ & 12 & 90 & (79) \\
\hline
\end{tabular}

${ }^{1}$ Actual - estimated. Estimated distributions of federal expenditures and tax burdens for $1987-89$ are based on the 1981-83 distributions.

Note: Numbers in parentheses denote negative numbers.

Source: Table 1.

1981-83 distribution. The "Difference" column is the difference between "Expenditures" and "Tax burdens."

To illustrate the impact of changes in the distributions of expenditures and tax burdens, consider what occurred in rural states. In 1987-89, estimated federal expenditures in rural states were $\$ 116.7$ billion, approximately $\$ 3.4$ billion below 
the actual level of $\$ 120.1$ billion (Table 3). ${ }^{13}$ Estimated federal tax burdens were $\$ 105.0$ billion, $\$ 6.6$ billion higher than the actual tax burden level of $\$ 98.4$ billion (Table 3). ${ }^{14}$ The estimated inflow of federal funds for rural states in 1987-89 was $\$ 11.7$ billion ( $\$ 116.7$ billion in expenditures less $\$ 105.0$ billion in estimated tax burdens). The actual net inflow of federal funds in rural states in 1987-89 was $\$ 21.7$ billion (Table 3). Therefore, an additional $\$ 10.0$ billion net inflow of federal funds in rural states in 1987-89 was due to higher-than-expected expenditures and lower-than-expected tax burdens (Table 6).

The data in Table 6 strongly suggest that changes in the distribution of federal tax burdens were more important in determining changes in the net flow of funds by region than changes in the distribution of expenditures. The only exceptions to this general finding are defense expenditures in low-income states, and the Southeast, Rocky Mountain, and Pacific regions; and nondefense expenditures in the Southwest. ${ }^{15}$ Expenditures accounted for 75 and 72 percent of the difference between the actual and estimated net inflows of defense expenditures in the Rocky Mountain and Pacific regions, respectively.

\section{IV.SUMMARY AND CONCLUSIONS}

When federal expenditures received within an area are compared to the federal tax burdens borne by the residents of that area, the overall fiscal system exhibits a slight tendency to redistribute resources to lower income areas. The system also responds to changes in economic circumstances. Those areas experiencing economic stress get an infusion of funds and a reduction in relative tax burdens, increasing the net inflow of funds (e.g., farm states). Conversely, those areas enjoying robust growth (urban states) face rising tax burdens due to the progressivity of the tax system and experience a decrease in their share of expenditures. However, the overall degree of redistribution is fairly small.

Studies of this nature invariably suffer from conceptual and procedural problems associated with comparisons of tax burdens and government expenditures. The major problem lies in the concept of comparing federal expenditures and tax burdens on a geographic basis. There are no universally accepted standards regarding how much, if any, geographic redistribution should take place. Thus, one cannot make any normative statements regarding the geographic redistribution that does occur through federal fiscal activities.

To a large extent, the geographic redistribution that does occur is accidental. Federal expenditure programs are designed to meet national requirements, although some programs do take local needs into account. Federal taxes are imposed to raise revenues and promote economic efficiency while complying with 
some accepted norms of equity. Only under extraordinary circumstances will the be benefits of federal expenditures within a region match the federal tax burdens borne by the residents of that region.

In addition to the major conceptual problem, a problem arises in estimating the benefits of federal expenditures. The benefits of certain federal programs such as national defense, international affairs, and general government functions, must, by their nature, be enjoyed to nearly the same degree by all citizens. Data on the location of where these expenditures are made give little indication of benefits accruing to the residents of that area. The benefits of federal expenditures for the construction, operation, and maintenance of major power, irrigation, conservation, and interstate highway projects are not necessarily limited to the place where they are made. For instance, if productive resources are fully employed in a given area, increased federal expenditures in that area may merely shift economic activity from one field to another with no increase in benefits.

Other problems inherent in expenditure data involve the completeness and reliability of the data. The major problem in studying the geographic distribution of federal expenditures is the exclusion of interest payments on federal debt. The lack of detail on subcontracting of large procurement contracts, and reporting expenditures such as wages and salaries at the location of the employing office may contain biases that limit the reliability of the data.

On the tax burden side of the equation, the major problem is the unknown bias that results from the lack of a consensus on the ultimate incidence of taxes imposed initially on business firms. All estimates of the geographic distribution of federal tax burdens require assumptions of how taxes are passed forward and/or backward (i.e., the ultimate incidence).

Despite such limitations, there are valid reasons for attempting to allocate the benefits of federal expenditures and tax burdens by geographic area. These estimates attempt to measure the extent to which federal fiscal activities affect regional economies, although the estimates are imperfect. Further research in this field should be in the direction of finding methods to allocate the benefits of government expenditures on a regional basis and comparing these estimates to estimates of the federal tax burden obtained using several allocation assumptions.

\section{ENDNOTES}

1. Two exceptions are Labovitz (1980) and Lawson (1985).

2. The term "burden" refers to the ultimate incidence of taxes rather than the place of original impact (i.e., where it is collected). 
3. Economic Recovery Tax Act of 1981, The Tax Equity and Fiscal Responsibility Act of 1982, The Surface Transportation Act of 1982, and The Tax Reform and Simplification Àct of 1986.

4. New England: Connecticut, Maine, Massachusetts, New Hampshire, Rhode Island, and Vermont; Mid Atlantic: Delaware, District of Columbia, Maryland, New Jersey, New York, and Pennsylvania; East North Central: Illinois, Indiana, Michigan, Ohio, and Wisconsin; West North Central: Iowa, Kansas, Minnesota, Missouri, Nebraska, North Dakota, and South Dakota; Southeast. Alabama, Arkansas, Florida, Georgia, Kentucky, Louisiana, Mississippi, North Carolina, South Carolina, Tennessee, Virginia, and West Virginia; Southwest: Arizona, New Mexico, Oklahoma, and Texas; Rocky Mountain: Colorado, Idaho, Montana, Utah, and Wyoming; Pacific: California, Nevada, Oregon, Washington, Alaska, and Hawaii. East: New England and Mid Atlantic; Midwest. East and West North Central; South: Southeast, Southwest, Oklahoma and Texas; West: Rocky Mountain, Pacific, Arizona and New Mexico.

5. All expenditures in foreign countries are excluded from the Census Bureau's coverage.

6. These excluded amounts are included in the Census Bureau's U.S. totals, but excluded in this paper.

7. The benefits of these expenditures are also received by foreigners.

8. Under certain conditions, incomes and employment may grow faster outside the state where the expenditures take place. Also, the recipient's perception of the benefits of government expenditures will diverge from the level of outlays due to restrictions on spending imposed by the grantor government.

9. Other weaknesses of collections data are illustrated by the individual and corporate income taxes. The withheld portion of employee income taxes is reported by the location of the employer, the nonwithheld portion is reported at the residence of the taxpayer. Often, these two collection points are different. Similarly, data on corporate income taxes are reported at the location of the corporate headquarters rather than where the economic activity takes place. Although the question of the ultimate incidence of this tax is still not settled, it is widely assumed that the tax is borne, in varying proportions, by employees, customers, and stockholders.

10. In comparing federal expenditures and federal tax burdens, it is implicitly assumed that all federal expenditures are financed by taxes. In reality, federal expenditures are financed by taxes, other revenues (fines, interest earnings, rents, royalties, sales of property, and other miscellaneous revenues), and debt. An unknown bias may exist by assuming that the distribution of tax burdens is similar to the distribution of other sources of federal revenues. 
11. Federal funds taxes exclude trust fund taxes (Social Security, Medicare, highway, airport and airway, etc.). These taxes do not finance defense spending; thus the burden of these taxes should not be compared to defense spending.

12. Estimates of defense and nondefense expenditures and tax burdens for 1981-83 and 1987-89 are available from the author upon request.

13. In 1981-83, rural states received 13.2 percent of all federal expenditures (Table 3). Applying this percentage to total federal expenditures in 1987-89 of $\$ 870.1$ billion yields an estimate of 1987-89 expenditures for rural States of $\$ 116.7$ billion.

14. Rural state residents bore 12.07 percent of the federal tax burden in 1981-83; applying this percentage to the 1987-89 level yields an estimated 198789 tax burden of $\$ 105.0$ billion

15. These data are not shown in Table 6, but are available from the author upon request.

\section{REFERENCES}

Anton, Thomas J. "The Regional Redistribution of Federal Expenditures: 1971-80," National Tax Journal 36, no. 4 (December 1983): 429-442.

Bahl, Roy, and J.J. Warford. "Interstate Distribution of Benefits from the Budgetary Process," National Tax Journal 24, no. 2 (June 1971): 169-76.

Dubin, Elliott. Geographic Distribution of Federal Funds in 1985. Agriculture and Rural Economy Division, Economic Research Service, U.S. Department of Agriculture. ERS Staff Report AGES89-7. Washington, D.C.: U.S. Government Printing Office, 1989.

Erdevig, Eleanor. "Federal Funds Flow No Bargain for Midwest," Economic Perspectives, Federal Reserve Bank of Chicago (January/February 1986).

Executive Office of the President, Office of Management and Budget. Historical Tables: Budget of the United States Government, Fiscal Year 1992. Washington, D.C.: U.S. Government Printing Office, January 1991. Budget of the United States Government, Fiscal Year 1991. Washington, D.C.: U.S. Government Printing Office, 1990.

Special Analysis: Budget of the United States Government, Fiscal Years 1981, 1982, 1983, 1987, 1988, and 1989. Washington, D.C.: U.S. Government Printing Office, January 1980, 1981, 1982, 1986, 1987, and 1988.

Labovitz, I. M. Flows of Federal Funds, 1952-76 (A-75). Advisory Commission on Intergovernmental Relations. Washington D.C.: U.S. Government Printing Office, June 1980. 
Lawson, Michael, "The Flow of Federal Funds," Intergovernmental Perspective (Spring/Summer 1985): 18-19.

Lowery, David, Stanley Brunn, and Gerald Webster. "The Spatial Impact of Reaganomics: A Test of Six Models," Growth and Change 19, no. 4 (Fall 1988): 49-67.

McKenzie, Richard B. "The Sunbelt/Frostbelt Confrontation: Economic Myths and Realities," Tax Review 63, no. 6 (September 1982) 32-35.

Merski, Paul. Federal Tax Burden by State. Tax Foundation Special Report. Washington, D.C.: U.S. Government Printing Office, May 1990.

Tax Foundation, Inc. Research Aid No. 5, Federal Tax Burdens in States and Metropolitan Areas. Washington, D.C., April 1974.

"Memorandum on the Allocation of the Federal Tax Burden and Federal Grants-in-Aid by State," Fiscal Year 1988. Washington, D.C., June 1988.

Tolley, George, Ronald Krumm, and Ricardo Garcia. Spatial Impacts of Federal Expenditure and Tax Policy. Mt. Pleasant, Mich.: Blackstone Co., 1986.

U.S. Congress House. Committee on the Budget. President Bush's Fiscal Year, 1991 Budget: A Summary and Analysis Prepared by the Staff of the House Budget Committee. Serial no. CP-3. Washington, D.C.: U.S. Government Printing Office, February 2, 1990.

U.S. Department of Commerce, Bureau of the Census. Federal Expenditures by State for Fiscal Year 1989. Washington, D.C.: U.S. Government Printing Office, March 1990. . Federal Expenditures by State for Fiscal Years 1981, 1982, 1983, 1987, and 1988. Washington, D.C.: U.S. Government Printing Office, March 1982, 1983, 1984, 1988, 1989.

U.S. Department of Commerce, Bureau of Economic Analysis. Survey of Current Business. Washington, D.C.: U.S. Government Printing Office, February 1991. 